\title{
Higher S2PLIT-UG scores at index admission are associated with a higher functional disease burden and increased biomarkers of myocardial injury and ventricular overload among patients with acutely decompensated heart failure
}

\author{
(iD) Josip Anđelo \\ Borovac $^{1,2,3 *}$ \\ (D)Joško Božić ${ }^{2}$, \\ (iD) Duška Glavaš ${ }^{2,3}$ \\ 'Institute of Emergency \\ Medicine of Split-Dalmatia \\ County, Split, Croatia \\ ${ }^{2}$ University of Split School of \\ Medicine, Split, Croatia \\ ${ }^{3}$ University Hospital Centre \\ Split, Split, Croatia
}

\begin{abstract}
KEYWORDS: heart failure, risk score, stratification, natriuretic peptides, troponin CITATION: Cardiol Croat. 2019;14(9-10):220. | https://doi.org/10.15836/ccar2019.220

*ADDRESS FOR CORRESPONDENCE: Josip Anđelo Borovac, Medicinski fakultet Sveučilišta u Splitu, Šoltanska 2, HR-21000 Split, Croatia. / Phone: +385-92-1721-314 / E-mail: jborovac@mefst.hr

ORCID: Josip Anđelo Borovac, https://orcid.org/0000-0002-4878-8146 • Joško Božić, https://orcid.org/0000-0003-1634-0635 Duška Glavaš, https://orcid.org/0000-0003-2649-0936

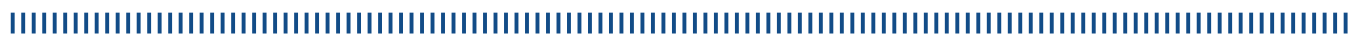

Goals: Outcomes following acutely decompensated heart failure (ADHF) are poor and associated with increased mortality and morbidity. Various risk stratification systems have been developed in the past to predict mortality and rehospitalizations in this population. The S PLiT-UG score was recently introduced to stratify ADHF patients in three risk categories in respect to all-cause mortality during 1-year post-discharge period. ${ }^{1}$ In this work, we aimed to determine associations of $\mathrm{S}_{2}$ PLiT-UG score with functional disease burden estimated by NYHA class and biomarkers including high sensitivity cardiac troponin I (hs-cTnI), NT-proBNP and C-reactive protein (CRP).
\end{abstract}

Patients and Methods: A cohort of 106 consecutive ADHF patients enrolled at the Cardiology Department during 2018-2019 were included in the study. S 2 PLiT-UG score calculation and laboratory analyses were performed for each patient at index admission.

Results: Fifty-six (52.8\%) patients were designated as low, 24 (22.6\%) as intermediate, and 26 (24.6\%) as high risk according to $\mathrm{S}_{2}$ PLiT-UG score stratification. Patients significantly differed $(\mathrm{p}=0.021)$ in respect to their NYHA class with mean values of $2.85 \pm 0.57,3.10 \pm 0.61$, and $3.33 \pm 0.56$ for low, intermediate, and high-risk group, respectively. Troponin values were significantly higher in high risk compared to intermediate and low-risk groups ( $148.4 \pm 72$ vs. $68.2 \pm 48$ vs. $42.2 \pm 24 \mathrm{ng} / \mathrm{L} ; \mathrm{p}=0.025$, respectively). Similarly, NT-proBNP levels were highest in the high-risk group $(13740 \pm 7884 \mathrm{pg} / \mathrm{mL})$ followed by intermediate $(7811 \pm 5668 \mathrm{pg} / \mathrm{mL})$ and low-risk group $(4195 \pm 1632 \mathrm{pg} / \mathrm{mL}), \mathrm{p}=0.002$. Finally, CRP values differed across groups with the high-risk group exhibiting highest CRP value $(21.8 \pm 14.8 \mathrm{mg} / \mathrm{L})$ compared to intermediate and low-risk group (17.5 \pm 15.8 and $12.2 \pm 11.3 \mathrm{mg} / \mathrm{L}$, respectively), however, this result was not significant $(p=0.327)$. S PLiT-UG score positively correlated with NYHA class $(r=0.300, p=0.004)$, hs-cTnI $(r=0.303, p=0.009)$, NT-proBNP $(r=0.353, p=0.001)$ and CRP $(r=0.203, p=0.069)$

Conclusion: Among ADHF patients, higher $\mathrm{S}_{2}$ PLiT-UG score values, calculated at index admission, are associated with higher functional disease burden and increased levels of circulating biomarkers reflecting myocardial injury and ventricular overload, but not systemic inflammation.
RECEIVED:

September 7, 2019

ACCEPTED:

September 16, 2019

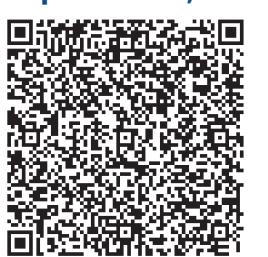

$\square$ Cardiologia Croatica 2019;14(9-10):220

LITERATURE IIIIIIIIIIIIIIIIIIIIIIIIIIIIIIIIIIIIIIIIIIIIIIIIIIIIIIIIIIIIIIIIIIIIIIIIIIIIIIIIIIIIIIIIIIIIIIIIIII

1. Borovac JA, Glavas D, Bozic J, Novak K. Predicting the 1-Year All-Cause Mortality After Hospitalization for an Acute Heart Failure Event: A RealWorld Derivation Cohort for the Development of the S2PLiT-UG Score. Heart Lung Circ. 2019 May 3. pii: S1443-9506(19)30351-8. doi: 10.1016/j. hlc.2019.03.021. [Epub ahead of print]. https://doi.org/10.1016/j.hlc.2019.03.021 